\title{
STIMULATION OF ASPEN ESTABLISHMENT ON UNRECLAIMED MINE SPOILS 1
}

\author{
Robert S. Hedin
}

and

\section{Elizabeth Ruch Hedin 2}

Abstract. The effect of surface amendments on the colonization of volunteer trees onto unvegetated coal spoils was tested. In the spring of 1989, barren acidic (pH 3.5) minesoil were treated with limestone (550 $\left.\mathrm{g} \mathrm{m}^{-2}\right)$, fertilizer $\left(75 \mathrm{~g} \mathrm{~m}^{-2}\right.$ of 5-10-5), and either chipped aspen stems or chipped aspen roots $\left(200 \mathrm{cc} \mathrm{m}^{-2}\right)$. The experimental design was a $2 \times 2 \times 3$ factorial with 3 replications. Surrounding the study area were patchy, but vigorous stands of volunteer aspens (Populus tremuloides and $P$. grandidentata) which produced copious seed in late May. Counts of aspen seedlings in the experimental plots were done at two week intervals from June to September. Germination of aspen seeds was increased by all treatments. The highest numbers of seedlings on June 18 were observed in fertilizer/root chip plots ( 218 seedlings $\mathrm{m}^{-2}$ ), limestone/root chip plots (140 seedlings $\mathrm{m}^{-2}$ ) and limestone/fertilizer/stem chip plots ( 121 seedlings $\mathrm{m}^{-2}$ ). Control plots had only 10 seedlings $\mathrm{m}^{-2}$. High mortality of seedlings was observed in all plots with the onset of dry, hot weather in July. Survival of seedlings only occurred in plots that received fertilizer. Although hot and dry weather continued through August, only minor further mortality was observed. On September 9, the highest seedling densities occurred in plots that received limestone, fertilizer and either type of wood chip treatments ( 11 seedlings $\mathrm{m}^{-2}$ ). Whether the chips were derived from roots or stems made no difference. Analyses of surface soil samples collected in September indicated that fertilizer and limestone amendments still had ameliorative effects on soil chemistry. Survival of aspen seedlings in acid, infertile minesoils cannot yet be determined. Monitoring of plots is continuing.

1 Paper presented at the 1990 Mining and Reclamation Conference and Exhibition, West Virginia, April 23-26, 1990.

2 Robert S. Hedin is a Research Biologist with the U.S. Bureau of Mines, Pittsburgh Research Center and Elizabeth R. Hedin is a horticulturalist with Horticultural Design, Pittsburgh, PA 15228.

\section{Introduction}

Volunteer aspens (Populus grandidentata and P. tremuloides) are important determinants of 
long-term successional trends on unreclaimed acidic minesoils in northern Appalachia (Hedin 1988). On sites where large numbers of aspens colonized the spoils soon after site abandonment, a forested plant community developed within 25 to 35 years. Where low numbers of aspens colonized, a poorly vegetated, open-canopied plant community developed. After 20 to 30 years of abandonment, these sites are typically characterized by groves of aspens separated by large areas of spoil that are either bare or covered with lichens and mosses. Because colonization of these open areas by trees is slow, the spoils appear destined to remain poorly vegetated for many decades.

Poorly vegetated minesoils are typically attributed to a combination of extremely low $\mathrm{pH}$ and high concentrations of exchangeable aluminum (Berg and Vogel 1973, Bell and Unger 1982, Ciolkosz et al. 1985). This explanation, however, cannot explain the existence of thriving stands of aspens in soils that are chemically similar to the bare soils. On one poorly vegetated site, the $\mathrm{pH}$ of surface soils under aspens averaged 3.9 , only $0.4 \mathrm{pH}$ units higher than bare soils (Hedin 1987). Most established aspens on these sites are slowly invading bare spoils by root sprouting. It is unlikely that aspen roots would invade these areas if the soil chemistry was toxic to aspens.

These observations led us to hypothesize that acidic minesoils remain barren for decades because soil characteristics are toxic to colonizing seedlings, not to established plants. This colonization "bottleneck" prevents the establishment of trees that could otherwise thrive on the site. If the bottleneck hypothesis is correct, then temporary moderation of the chemical conditions of the minesoils should cause colonization by aspens that, once sufficiently established, will survive and grow long after the moderating conditions dissipate. In this paper, we report first year results of an experiment designed to test the bottleneck hypothesis by amending extremely acidic barren minesoils with treatments of limestone, fertilizer and wood chips.

\section{Study Site}

The experiment is being conducted on strip mine spoils three miles west of Emlenton, Pennsylvania. Lower Allegheny coals (Clarion, Brookville) were mined in the early 1960's. Although the site was planted with pine, spruce, and larch tree seedlings before abandonment, mortality appears to have been very high. Currently, most of the spoils are either barren or sparsely vegetated with a mixture of planted trees and volunteer plants. Isolated volunteer trees, typically aspen, black birch (Betula lenta), red maple (Acer rubrum or oak (Quercus alba, Q. imbricaria, and Q. velutina) are scattered across the site. Where several aspens colonized the same area, root sprouting has sometimes resulted in small groves of trees. The dominant herbaceous plants are the bunch grasses, broomsedge (Andropogon virginicus) and poverty grass (Danthonia spicata). Coverage of grasses is highest in drainage areas. Except for these grassy patches and within dense groves of aspens, the spoils are generally bare. Despite copious annual production of wind born seeds by aspen, broomsedge and poverty grass, successful colonization of the bare minesoils has been minimal during the last several decades.

\section{Materials and Methods}


grid was established that contained 49 plots, each $2 \mathrm{~m}$ by $2 \mathrm{~m}$. On April 30 , the plots were treated with surface applications of limestone, fertilizer, and wood chips. Rates of application are shown in Table 1. Limestone raised $\mathrm{pH}$ and provide calcium and magnesium. Fertilizer provided nutrients (N, P, K). Root chips were applied as a mycorrhizal inoculant, while stem chips were applied as non-mycorrhizal control. Chip treatments should not be considered a mulch. The application rates $w$ re so light (two sandwich bags of chips per 4 my plot) that affects on soil moisture or soil temperature likely did not occur.

The wood chips were obtained by cutting branches and digging roots from aspen trees growing on the site and chipping them with a standard brush chipper. Care was taken to ensure that no contamination of the stem chips with roots occurred. Between preparation and application, chips were stored in black plastic bags at $20^{\circ} \mathrm{C}$. During this 10 -day period, the root chips became covered with fungal mycelia. No growth of mycelia was observed on stem chips.

Table 1. Amendment Applications Rates used in the
Experiment

The experimental design was a $2 \times 2 \times 3$ factorial replicated three times for a total of 36 plots. Treatments combinations were assigned to the plots randomly. In addition to the three control plots included in the experimental design, nine additional control plots were established adjacent and up-gradient of the experimental area and are reported as an outside-plot control.

The number of tree seedlings in each of the plots was observed from May 28 through September 9, 1989 at two week intervals. In May and June, when seedlings were tiny and numerous, numbers were estimated by counting all seedlings within a $0.05 \mathrm{~m}$ frame that was placed at four random locations within each plot. During the rest of the summer, counts of all seedlings were made. On August 5, August 20 and September 9, the height of each seedling was measured.

Seven surface soil samples were collected from the experimental area in April (before amendment application). Ten surface samples were collected from various experimental plots in September. Several samples were also collected from various locations on the site outside of the study area. Samples were analyzed by The Pennsylvania State University. Soil pH, P (Bray determination), acidity and exchangeable cations were determined by the Merkle Laboratory. Metals were determined by the Soil and Environmental Chemistry Laboratory using a DTPA extraction procedure (Baker and Amacher 1981).

\section{$\underline{\text { Results and Discussion }}$}

\section{$\underline{\text { Soil Analysis }}$}


Unamended surface soils in the experimental area were extremely acidic, with high concentrations of available aluminum and low concentrations of available phosphorous and base cations (Table 2). Acidity, $\mathrm{pH}$ and aluminum levels were in ranges typically considered toxic to plants (Ciolkosz et al. 1985). Two surface samples, collected from bare soils under an established bigtooth aspen and under recent root sprouts, had soil chemistries similar to bare soils (Table 3 ). Soil collected from the rooting zone in a dense aspen grove was less acidic, but $\mathrm{P}$ and $\mathrm{Al}$ levels were the same as samples from bare areas.

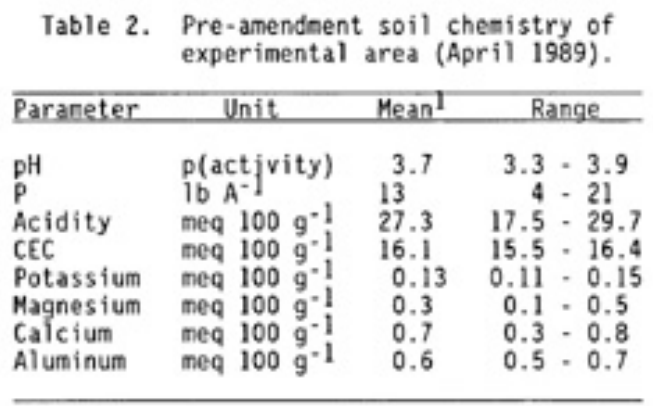

$1_{\text {Mean of seven samples. }}$

Table 3. Soil chemistry in bare areas and in vegetated areas.

\begin{tabular}{lrrrrrrrrr}
\hline & pH & P & ACid & CEC & K & Ng & Ca & All \\
\hline Experimental area 2 & 3.7 & 13 & 27.3 & 16.1 & 0.1 & 0.3 & 0.7 & 0.6 \\
Bare under adult aspen & 3.6 & 9 & 23.6 & 16.9 & 1.3 & 3.8 & 5.9 & $N^{3}$ \\
Bare under aspen sprout & 4.0 & 21 & 27.3 & 16.0 & 0.6 & 2.2 & 3.1 & NA \\
Root zone soil in aspen grove & 4.1 & 27 & 16.3 & 16.5 & 0.3 & 0.5 & 0.8 & 0.5 \\
\hline
\end{tabular}

1 See Table 3 for units.

2Mean of seven determinations (from Table 2).

3 Not available.

Table 4. Soil chenistry in experimental plots in September 1989.1

\begin{tabular}{lrrrrrrrr}
\hline & pH & P & Acid & CEC & K & Mg & Ca & A1 1 \\
\hline Control & 3.6 & 11 & 16.8 & 16.3 & 0.9 & 0.7 & 0.8 & 0.6 \\
Linestone & 6.2 & 17 & 2.4 & 12.9 & 0.9 & 4.7 & 75.6 & NA \\
Line/Fert & 7.1 & 78 & 0.0 & 13.9 & 0.20 & 0.7 & 13.3 & $<0.1$ \\
Line/Fert/Stens & 5.9 & 81 & 4.9 & 14.4 & 0.19 & 0.6 & 8.7 & $<0.1$ \\
Line/Fert/Roots & 6.8 & 80 & 1.0 & 13.1 & 0.20 & 0.7 & 13.4 & $<0.1$ \\
\hline
\end{tabular}

$1_{A 11}$ values the average of two samples, see Table 3 for units.

All soil samples collected in September still showed the effects of spring amendment applications (Table 4). Limestone plots had circumneutral $\mathrm{pH}$, low acidity and high levels of exchangeable calcium. Fertilizer plots still had circumneutral $\mathrm{pH}$ and moderate phosphate levels. Control plots had low pH and high aluminum levels typical of unamended soils.

\section{Aspen Colonization, Survival, and Growth}

Aspen trees produced seed in late May. The viability of these seeds was tested by collecting several dozen seeds from trees surrounding the plots and subjecting them to ideal growing conditions in a greenhouse. Within a week, $90 \%$ had germinated. 
On May 28, numerous aspen seeds were observed in all experimental plots, but no germination was evident. During the next week, the study site experienced cool and rainy weather that likely produced ideal weather conditions for seed germination.

By June 6 , seed production by aspens had ceased and numerous aspen seedlings were observed in many experimental plots (Table 5). Because many aspen seeds blew into the plot clumped together or still attached to catkins, the seedlings were often found in discrete groups within plots. This variation made it impossible to distinguish significant differences between treatments.

On June 18 , similar numbers of seedlings were observed in the experimental plots. None of the treatment averages differed significantly between June 6 and 18 (tested by individual ANOVA tests for each treatment). Thus, germination of aspen seeds was largely complete by this date. No mortality of seedlings was evident on this date.

Higher germination of aspens was observed in control plots within the study area than controls adjacent to the study area (control-in and control-out, respectively, in Table 5). This difference likely resulted from some movement of chemical amendments on treated plots to untreated plots during rainstorms in May and June. Two plots contained all of the seedlings observed in the control in plots and they were both immediately down-slope of plots that received fertilizer and limestone amendments.

Table 5. Number of Pqoulus (Aspen) seedings observed in experimental plots per $\mathrm{m}^{2}$.

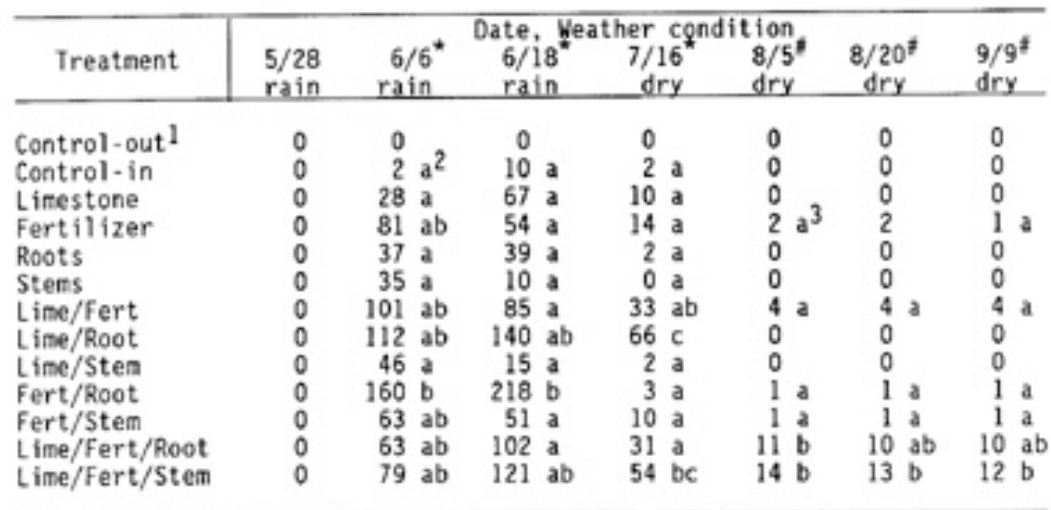

*Estinates based on counts of seedlings in four $0.05 \mathrm{~m}^{2}$ frames in each plot.

Actual count of all seedlings.

$1_{\text {Average of eight plots, adjacent and up-gradient of experimental }}$ area that did not receive any amendments.

2 Means with same letter within the same column are not significantly

different at 0.05 significance level (Student-Newman-Keuis test).

${ }^{3}$ Only plots containing aspen seedlings were included in statistical

comparison of means on $8 / 5,8 / 20$, and $9 / 9$.

The site was visited on June 30 , but counts of seedlings were not made. Close inspection of the plots, however, did not indicate stressful conditions or mortality of seedlings.

In July, weather at the study site turned hot and dry. During the month, widespread mortality of seedlings occurred. By August 5, complete mortality had occurred in control, limestone, and wood chip plots. Seedlings in the limestone/root chip plots, which had some of highest densities during the first six weeks of the experiment, experienced complete mortality. Two patterns of mortality were observed. In plots not receiving fertilizer, seedlings grew very 
little after germination. During July, these tiny seedlings turned red and gradually died, probably from stress associated with phosphorus deficiency (Salisbury and Ross 1978). This pattern contrasted sharply with several of the fertilizer plots, where seedlings grew tall and spindly during June. By mid-July, many of these seedlings had wilted and died.

Although mortality in fertilizer plots was high, survival of some seedlings was observed in all treatments. In particular, significant survival was observed in plots that received both limestone and fertilizer treatments.

Throughout August, hot and dry weather continued. However, further mortality of seedlings was limited (Table 5, see also total counts in Table 6). Most of the plants that had survived grew 3-5 cm in August and developed several more sets of leaves. Seedlings that did die were primarily those that were very small. The primary source of mortality for larger seedlings $>5$ $\mathrm{cm}$ height) appeared to be physical damage caused by human or deer movement through the experimental plots.

By the end of summer, seedlings had grown to an average height of $8.0 \mathrm{~cm}$ (Table 6). Several seedlings grew to $20-25 \mathrm{~cm}$. The tallest plants were in plots receiving limestone, fertilizer, and either wood chip amendment.

Table 6. Mean height of aspens in treatments containing seedlings.

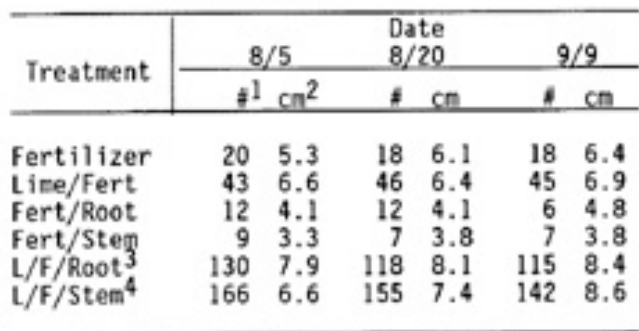

${ }_{2}^{1}$ Total number of seedlings in three plots.

${ }^{2}$ Average height of seedlings in $\mathrm{cm}$.

3 Limestone/fertilizer/root.

$4 \mathrm{~L}$ imestone/fertilizer/stem.

\section{Summary}

The first year results of this experiment indicate that the absence of aspen trees on poorly vegetated acidic spoils is caused by a colonization bottleneck that can be removed through the application of one or more surface amendments. The bottleneck has two aspects: 1) germination of aspen seeds is inhibited by extreme chemical conditions, and 2) extreme physical conditions in summer months cause high seedling mortality. The most likely chemical inhibition of germination is low pH. Although no specific tests with aspens have been conducted, numerous experiments with other plants have shown that soil $\mathrm{pH}$ values less than four greatly reduce germination percentages (Foy et a] . 1978). By raising the $\mathrm{pH}$ of minesoils with either fertilizer or limestone applications, mass germination of aspens was stimulated. The slight germination of seeds that occurred in experimental plots that did not receive direct applications of limestone or fertilizer, but were likely affected by alkaline runoff from adjacent plots, illustrates the minor chemical change necessary to stimulate aspen germination. It also illustrates the need for buffer strips between treatment plots in future experiments. 
Once established, aspen seedlings are subjected to temperature and moisture stresses that can cause high mortality (Deely and Borden 1972). The minimal energetic reserves contained in tiny aspen seeds prevent rapid development of an extensive root system and make them particularly vulnerable to these stresses. Bare minesoils are subject to rapid and extreme changes in temperature and moisture because they receive direct sunlight, are wind swept, and have little organic matter (Bell and Ungar 1982). During July the study area experienced normal hot and dry weather, causing high mortality of seedlings. Survival was only observed in plots that received fertilizer, suggesting that in the absence of nutrient additions, aspen seedlings cannot develop root systems extensive enough to survive normal summer stresses. Although limestone, by itself or in combination with wood chips, did not promote seedling survivorship, a very strong positive interaction with fertilizer occurred. One interpretation of this interaction is that the "double-dose" of limestone and fertilizer resulted in a deeper zone of soil amelioration and thus facilitated deeper root systems. Further experiments testing different levels of amendments, as well as soil sampling along a depth gradient are necessary to better understand the basis of this interaction.

Although applications of wood chips in combination with limestone and fertilizer had a significant effect on seedling survivorship (Table 5), a mycorrhizal factor cannot be implicated at this time. Medve et al. (1977) applied macerated roots to mine spoils and attributed subsequent colonization by aspens to a mycorrhizal effect. The present experiment was designed, in part, to test these findings by comparing mycorrhizal (root) and nonmycorrhizal (stem) wood chip treatments. Surprisingly, both treatments had beneficial effects on seedling survivorship in plots that also received limestone and fertilizer.

Statistically, the two chip treatments cannot be distinguished. Either chip treatment provides a benefit unrelated to the presence/absence of mycorrhizae, or chipped aspen stems are not the non-mycorrhizal control intended. The hypotheses cannot be currently evaluated as we have not yet inspected the roots of aspen seedlings to evaluate mycorrhizal infection.

Final evaluation of this experiment is not possible until the chemical effects of the amendments dissipate. In most previous experiments where acidic mine spoils were amended with fertilizer and limestone and planted with nursery stock trees or agronomic herbaceous species, high mortality of the planted species occurred when amendment effects dissipated. The important difference between those efforts and the present experiment is that native, self-colonizing aspens were used. As already noted, established aspens can grow in extremely acidic, infertile spoils (Table 3 ). The important question is not whether aspens can survive in these soils but how long an aspen seedling must be subsidized with chemical amendments before it can survive in an unamended mine soil.

If the experiment proves successful, an easy method of revegetating acidic, barren spoils with native aspen would be to apply enough limestone and fertilizer to stimulate germination and establishment. A similar procedure has been used to revegetate acidic, metal -contaminated soils in the Sudbury, Ontario area (Winterhalder 1988). The cost of the fertilizer and limestone combination used in the experiment is less than $\$ 150$ per acre. Application of the amendments can be done by hand or with conventional farm machinery. Thus the cost and needs of this method would be within the resources of many local groups who currently perceive the revegetation of barren mine sites as an impossibly expensive, engineeringintensive undertaking. 


\section{Literature Cited}

Baker, D. E. and M. C. Amacher. 1981. Development and interpretation of a diagnostic soil testing program. Penna. Agr. Exp. Sta. Bull. 826, University Park, PA.

Bell, T. J. and I . A. Ungar. 1982. Factors affecting the establishment of natural vegetation on a coal strip mine in southeastern Ohio. Am. Mid. Nat., 105:19-31.

Berg, W. and W. Vogel . 1973. Toxicity of acid coal-mine spoils to plants. p. 57-67. In: R. Hutnik and G. Davis (eds.) Ecology and Reclamation of Devastated Land, Vol I., Gordon and Breach, New York.

Ciolkosz, E. J., Cronce, R. C., Cunningham, R. L. and G: W. Petersen. 1985. Characterization, genesis, and classification of Pennsylvania minesoils. Soil Sci., 139:232-238.

Deely, D. J. and F. Y. Borden. 1972. p. 69-79. High surface temperatures on strip-mine spoils. In: R. Hutnik and G. Davis (eds.) Ecology and Reclamation of Devastated Land, Vol I., Gordon and Breach, New York.

Foy, C. D., R. L. Chaney and M. C. White. 1978. The physiology of metal toxicity in plants. Ann. Rev. Plant Phys., 29:511-566.

Hedin, R. S. 1987. The consequences of strip mine reclamation: vegetation and economics of reclaimed and unreclaimed sites in west-central Pennsylvania. Ph.D. Thesis. Rutgers University, New Brunswick, NJ, 314 p.

Hedin, R. S. 1988. Volunteer revegetation processes on acid coal spoils in northwestern Pennsylvania. p. 111-117. In: Mine Drainage and Surface Mine Reclamation, Volume II. U.S. Bureau of Mines, IC 9184.

Medve, R. J., Hoffman, F. and T. Gaither. 1977. The effects of mycorrhizal -forming amendments on the revegetation of bituminous stripmine spoils. Bull. Torrey Bot. Club, 104:218-225.

Salisbury, F. and C. Ross. 1978. Plant Physiology. Wadsworth Publishing Co., Belmont, CA., p. 422.

Winterhalder, K. 1988. Trigger factors initiating natural revegetation processes on barren, acid, metal-toxic soils near Sudbury, Ontario smelters. p. 118-124. In: Mine Drainage and Surface Mine Reclamation, Volume 11. U.S. Bureau of Mines, IC 9184. 